\title{
Measuring the ICT competencies in Slovakia and in Serbia in the higher education
}

\author{
Gabor Kiss ${ }^{1 \mathrm{a}}$ \\ ${ }^{1}$ J. Selye University, Department of Mathematics and Informatics, Bratislavská cesta 3322, 945 01, \\ Komárno, Slovakia
}

\begin{abstract}
The purpose of this study is to identify the levels of ICT Competencies of university students from two universities, one in Slovakia and the other in Serbia. The research type is quantitative and exploratory. The instrument consists of 14 items related to three types of competencies: Basic, Application and Ethical. The quantitative data analysis was performed with SPSS software using descriptive statistics and MannWhitney independent sample $U$ test. The situation of education in Slovakia and Serbia is not so very different although each country has taken different paths in the field. The results referring to Slovakian and Serbian students' perceptions of their competencies in ICT indicate that they perceive themselves as having high levels of competencies in ICT. These results suggest the need to develop strategies that promote the effective use of technology resources by both students and teachers.
\end{abstract}

Keywords: ICT Competencies; Slovakia and Serbia; university students

\section{Introduction}

The purpose of this study is to identify the level of ICT Competencies of university students from Slovakia and Serbia.

The research type is quantitative. The methodological strategy used was the replication of the instruments used by one of the authors in another international research project where perceptions of teachers and students from two Mexican universities (Veracruzana University and Chihuahua University) and one Spanish university (Salamanca University) were compared [1]. However, in this paper the results of an exploratory study comprising just one dimension of the instruments that were applied are shown: Students' levels of ICT competencies.

The instrument for measuring students' ICT competency is composed of 14 items. The reliability of the questionnaire obtained by the Cronbach technique was 0.81 . The design of the instrument included the Likert scale with four categories: "Not at all, A little, Quite a lot and A lot". For the purposes of this study it is assumed that students having a certain level

\footnotetext{
${ }^{a}$ Corresponding author: kiss.gabor@bgk.uni-obuda.hu
} 
of competency fit into the categories "Quite a lot" and "A lot" while, the absence or deficiency in competencies is represented by "Not at all" and "A little".

Table 1. contains the types of competencies and their associated items following the analytical proposal of García-Valcárcel and Arras regarding the division into three types:

(1) Basic Competencies;

(2) Application Competencies; and

(3) Ethical Competencies.

Table 1. Types of competencies

\begin{tabular}{|l|l|}
\hline Basic competencies & $\begin{array}{l}\text { You use the main informatics and network resources. } \\
\text { You use the applications in a productive way. } \\
\text { You apply the digital tools to obtain information from varied sources. } \\
\text { You make use of models and simulations to explore complex topics. } \\
\text { You interact and collaborate with your partners, using a variety of digital } \\
\text { recourses. }\end{array}$ \\
\hline $\begin{array}{l}\text { Application } \\
\text { Competencies }\end{array}$ & $\begin{array}{l}\text { You communicate in an effective way the information and ideas, using a } \\
\text { variety of media and formats. } \\
\text { You participate in groups that develop project for the production of } \\
\text { original works or solve problems. } \\
\text { You solve problems, and make decisions using the appropriate tools and } \\
\text { digital resources. } \\
\text { You plan and organize the required activities to solve a problem or make } \\
\text { a project. } \\
\text { You create original works as a medium of personal expression. }\end{array}$ \\
\hline Ethical Competencies & $\begin{array}{l}\text { You select, analyze, and make ethically correct use of the information } \\
\text { obtained. } \\
\text { You make rational, legal and responsible use of information using ICT } \\
\text { You value ICT as an instrument of permanent learning. } \\
\text { You value ICT as a medium of collaboration and social communication }\end{array}$ \\
\hline
\end{tabular}

\section{ICT competencies}

The training process of college students focuses on developing a set of competencies in order to acquire their college degrees. In this sense, we can point to at least two large blocks which are common at the international level: generic and specific competencies [2].

Within the preferred generic competencies that apply in most of the university educational programs on the international level, we find ICT competencies identified by various international education programs (UNESCO, ODM, EPT, DNUA, DEDS).

In this sense, according to Fuentes [3], we could say that competency is: A set of knowledge, skills, attitudes, and values that is needed to effectively perform an occupation or a productive role. Ina similar way Yañez-Galecio [4] affirms that competency could be seen as an attribute of a person: specifically competency can be related to his/her success in the performance of a task. In this way failure is seen as the absence or low level of development of one or several competencies associated with a specific activity.

Meanwhile, Tobón [5]. defines competency as the integrated actions performed by a person in order to carry out activities and solve problems, based on certain eligibility criteria, continuous improvement and ethics. So, it can be said that ICT competencies are a group of skills, knowledge and attitudes that are applied to the use of information and communication systems, as well as the devices that the activity involves and, according to NETS for Students [6], also the knowledge that people should have and be able to learn and transfer, effectively, in order to live productively in a digital world.

Thus, these ICT competencies are being taken into consideration in the educational standards that various countries have developed in the form of profiles, such as NETS in the United States, the Official certificate in Computing and Internet (B2i) in France, the 
incorporation of ICTs indicators in the National Curriculum in England, as well the transversal integration of the ICTs in schools, in Belgium [1].

Also in Hungary and Slovakia national policies have even been working on increasing the development of these ICT competencies in their teachers and students. But the results are quite different as we will discuss later. We could say that Hungary has developed its own standards for developing ICT competency, but Slovakia followed a little bit other way to give more free hand for the teachers.

Hence many international authorities describe key points of the educational development of ICT-literate students. For instance, NETS includes: the ability to make Web designs, presentations, databases, and the ability to use graphics software, spreadsheets, databases, online applications, e-mail, chat applications and word processors, among others. Moreover, UNESCO [7] has presented the ICT competency standards for teachers, which combines the requirements for teachers and students in today's world and emphasizes the current importance of ICT for all countries, including the members of the OECD [8].

Finally it is relevant to say that according to UNESCO, Competencies in ICT can be classified as: (a) digital literacy competencies, (b) application competencies and (c) ethical competencies. So, the core competencies of digital literacy (a) are related to the use of ICT in classroom presentations and activities, and involve the use of digital tools to obtain information, and the use and development of materials obtained from various online sources. Meanwhile, application competencies (b) are related to the use of skills and knowledge to create and manage complex projects, solve problems in real-world situations, collaborate with others, and make use of information and networks of experts. Finally ethical competencies (c) are related to the ethical, legal and responsible use of ICT [9].

\section{Information technology education in Slovakia}

The education of Informatics from the 2 nd grade has been compulsory since the school year of 2008/2009, since the introduction of the school reform but it also appears in the 1st grade as well as in the nursery school curriculum though not as a compulsory subject. It is compulsory to have 1 Informatics lesson a week in the junior section and 0.5 lesson a week in the senior section that can be raised by the schools' own programme. Some schools took the opportunity and increased it to 1 lesson a week. The National Educational Programme does not assign precisely what teachers have to teach in the various grades but announces the school leaving standards to reach at the end of the senior section. So it does not matter if programming is taught in the 6th grade in one school and in the 8th grade in another school; the aim is to reach the school leaving standards. It is part of the educational programme of the school how its students should reach these standards, how many lessons they have a week and at what pace they learn the material; this programme is accepted by the management of the school and its teachers together .

The National Educational Programme divides Informatics into 5 topics (it does not specify the number of lessons):

1. Information around us

2. Communication with the help of the means of the ICT

3. Problem solving, thinking with the help of algorithms

4. Basic principles of the operation of the ICT tools

5. IS society

These 5 topics are then to be divided into the school leaving standards. 


\section{Information technology education in Serbia}

The education of Informatics from the 1 nd grade has been compulsory since the school year of 2008/2009, following the National Educational Program. It is compulsory to have 1 Informatics lesson a week in the junior section (1st-4th grades) [10, 11]. The learning material include the basic knowledge about computer, Painting program, Word processing, Presentation and e-mail. In the senior section (7th-8th grades) is it just selectable on basic level. The learning material include programming, creating web pages and using multimedia devices. The students have to chance to choose the technical-informatics direction, in that case they spend 2 lessons a week with this subject.

In the secondary grammar school have the students more chance to learn more about ICT. In generally 2 lessons per week is the opportunity the learn ICT, except the students in Art school, where they learn ICT just in the first grade. The learning material include programming, database management and Web 2.0 materials. The students in a specialized secondary grammar schools (natural science and computer science) can spend 12 lessons per week with ICT. The problem is the learning material is not parallel with ECDL, it gives not same knowledge [8].

The Serbian students get more ICT lessons from the 1st grade to the end of the secondary grammar school, than the Slovakian students.

Our starting hypothesis after get to know the Serbian and the Slovakian ICT Education, the Serbian Students will reach better results.

\section{Analyzing students' ICT competencies}

The purpose of this study is to compare the ICT competencies of students from Slovakian and Serbian universities.

The number of participants: The sample consisted of 440 students, 226 Serbian and 214 Slovakian students (Table 2.).

Table 2. The number of participants by gender and country

\begin{tabular}{|c|c|c|c|}
\hline & Male & Female & Total \\
\hline Serbian & 92 & 134 & 226 \\
\hline Slovakian & 107 & 107 & 214 \\
\hline Total & 199 & 241 & 644 \\
\hline
\end{tabular}

\subsection{Differences in Competencies by countries}

The students filled out a self-reported questionnaire with 14 items. We have used Likerttype rating scales to measure the ICT competency level of students [12]. Likert scales are commonly used by self-reported questionnaire, providing a range of responses to a given question or statement [13].

The Likert scale is ordinary scale, and as such we can calculate mean, min, max, median, modus, std. dev. etc. We can use the non parametic tests where we need ordinary variables. We have two independent samples so we could use the Mann-Whitney-Wilcoxon test for 2 samples [14]. The Mann-Whitney-Wilcoxon test seems better choice versus $t$ test by Likert-type data [15], because it is testing the medians of the samples.

We used the Mann-Whitney independent sample U test of SPSS to compare the means of scores taken by the students. Monitoring was held on $\mathrm{p}=5 \%$ significancy level in the whole analyzing process. 
Table 3. Levels of Competencies Questions by university and results of the Mann-Whitney-Wilcoxon test

\begin{tabular}{|c|c|c|c|c|}
\hline Item & $\begin{array}{l}\text { Media } \\
\text { Global }\end{array}$ & Serbia & Slovakia & Sig. \\
\hline $\begin{array}{l}\text { You use the main informatics and } \\
\text { network resources. }\end{array}$ & 2,87 & 2,99 & 2,74 & $\mathbf{0 , 0 0}$ \\
\hline $\begin{array}{l}\text { You use the applications in a } \\
\text { productive way. }\end{array}$ & 2,77 & 2,89 & 2,64 & $\mathbf{0 , 0 0}$ \\
\hline $\begin{array}{l}\text { You apply the digital tools to obtain } \\
\text { information from varied sources. }\end{array}$ & 2,93 & 3,01 & 2,85 & $\mathbf{0 , 0 0}$ \\
\hline $\begin{array}{l}\text { You select, analyze, y realize an ethic } \\
\text { use of the obtained information. }\end{array}$ & 2,69 & 2,82 & 2,56 & $\mathbf{0 , 0 0}$ \\
\hline $\begin{array}{l}\text { You communicate in an effective way } \\
\text { the information and ideas, using a } \\
\text { variety of media and formats. }\end{array}$ & 2,85 & 2,93 & 2,76 & $\mathbf{0 , 0 0}$ \\
\hline $\begin{array}{l}\text { You make use of models and } \\
\text { simulations to explore complex topics. }\end{array}$ & 2,20 & 2,36 & 2,04 & $\mathbf{0 , 0 0}$ \\
\hline $\begin{array}{l}\text { You interact and collaborate with your } \\
\text { partners, using a variety of digital } \\
\text { recourses. }\end{array}$ & 3,00 & 3,01 & 2,98 & 0,56 \\
\hline $\begin{array}{l}\text { You participate in groups that develop } \\
\text { project for the production of original } \\
\text { works or solve problems. }\end{array}$ & 2,91 & 2,93 & 2,89 & 0,61 \\
\hline $\begin{array}{l}\text { You solve problems, and make decisions } \\
\text { using the appropriate tools and digital } \\
\text { resources. }\end{array}$ & 2,77 & 2,81 & 2,73 & 0,16 \\
\hline $\begin{array}{l}\text { You plan and organize the required } \\
\text { activities to solve a problem or make a } \\
\text { project. }\end{array}$ & 2,75 & 2,83 & 2,66 & $\mathbf{0 , 0 1}$ \\
\hline $\begin{array}{l}\text { You create original works as a medium } \\
\text { of personal expression. }\end{array}$ & 2,20 & 2,33 & 2,07 & $\mathbf{0 , 0 0}$ \\
\hline $\begin{array}{l}\text { You make a rational, legal and } \\
\text { responsible use of the information } \\
\text { through the ICT }\end{array}$ & 2,72 & 2,77 & 2,68 & $\mathbf{0 , 0 1}$ \\
\hline $\begin{array}{l}\text { You value the ICT as an instrument of } \\
\text { permanent learning. }\end{array}$ & 3,02 & 3,00 & 3,05 & 0,26 \\
\hline $\begin{array}{l}\text { You value the ICT as a medium of } \\
\text { collaboration and social } \\
\text { communication. }\end{array}$ & 2,82 & 2,92 & 2,70 & $\mathbf{0 , 0 0}$ \\
\hline
\end{tabular}

According to the Mann-Whitney-Wilcoxon test significant differences were found in at least 10 different items.

Figure 1 shows an overview of the profile that exists in the various dimensions of ICT competencies levels. It is clear that similar levels exist between students from the two countries. However the dimension of Application Competencies presents a major difference 
in favor of Serbian students. Basic and Ethical Competencies show very similar values, being slightly higher for the Serbian students.

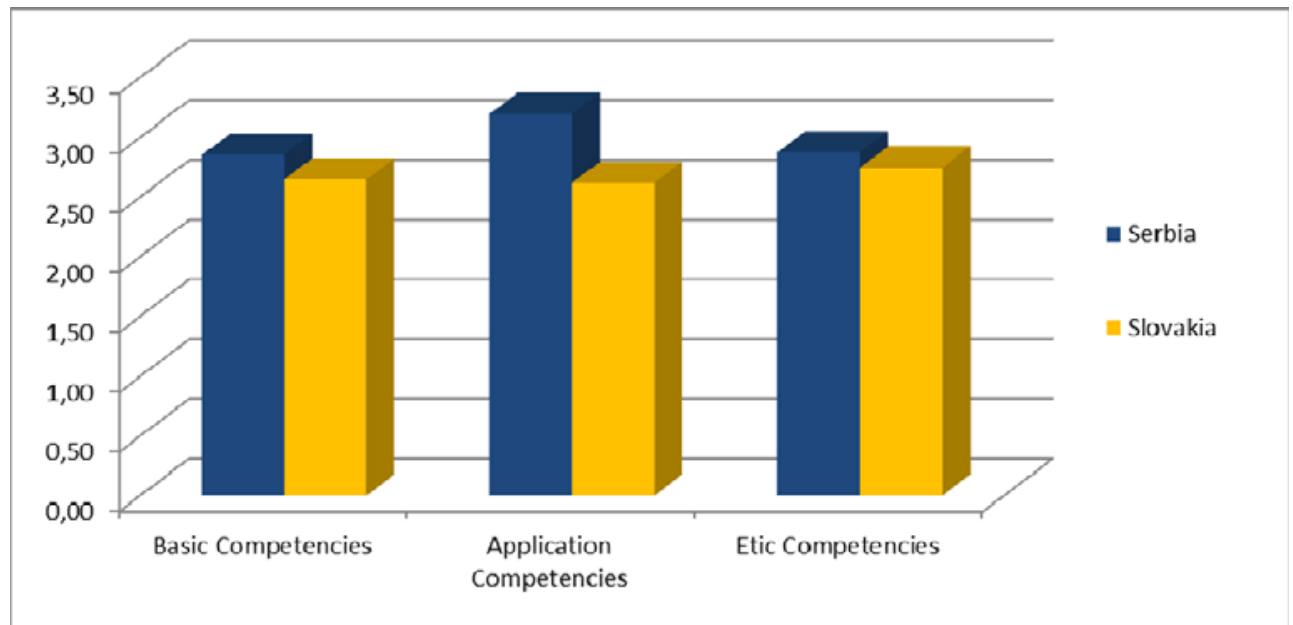

Fig. 1. Means of competencies dimensions: Differences by country

\subsection{Creation percentages by dimension}

To provide further details on the manner in which students from both countries recognize themselves as competent in various activities relating to the use of ICT, the percentages obtained for each item comprising the three different dimensions are presented. The activities in which students claim to be highly proficient (at or above $75 \%$ values) are also pointed out.

Basic Competencies can be considered basic for proper scholarly performance. This type of dimension is related to activities such as interaction with others through the digital media, the use of models to explore complex topics, the application of tools used to find information from various sources, the productive use of applications and the use of the main informatics resources (Fig. 2.).

The percentages obtained in this dimension, indicate the presence of an acceptable level of competency for the students of Slovakia and Serbia in many areas. However, in the item referring to the use of models to explore complex topics, a lower level of competence was obtained. The percentage was higher for the Serbian students $(39.8 \%)$ in comparison to Slovakian students (19.2\%).

Meanwhile in interaction through the use of digital resources, there is a higher level of competency for the Slovakians $(80.8 \%)$ compared to the Serbians $(79.2 \%)$. In the use and application of digital tools to obtain information from a variety of resources, a new there is a higher level of competency in the Serbian students (82.7\%) than the Slovakian students (77.1\%).

Finally, in reference to the productive use of the applications, and the use of the main informatics resources, we find that there is a major degree of competencies in the students from Slovakia $(61.7 \%$ and $71.0 \%)$ compared to the students from Serbia $(77.4 \%$ and $88.1 \%)$. 


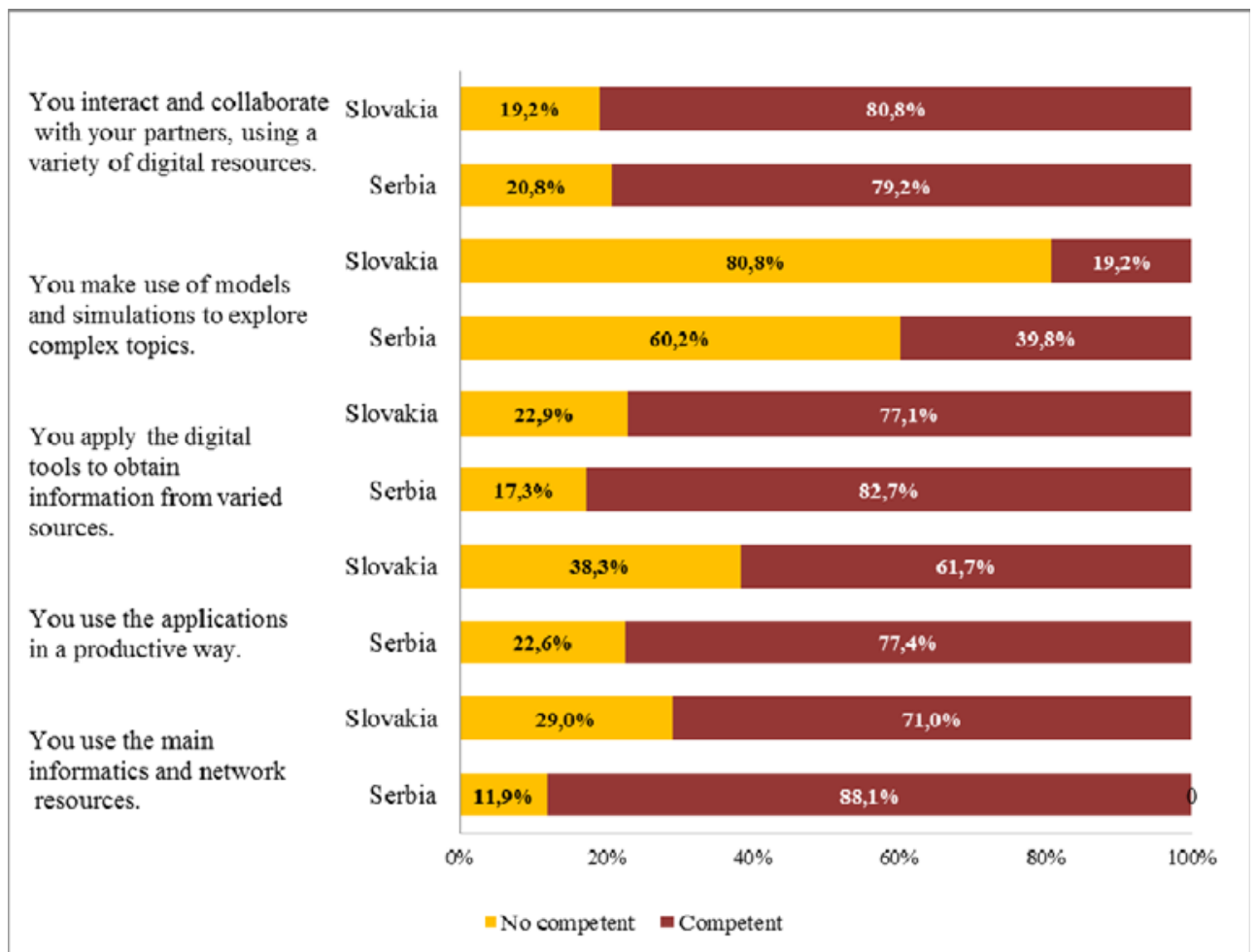

Fig. 2. Means of competencies dimensions: Differences by country

The items rated highest by the Serbian students are those related to the use of the main informatics and network resources and the application of digital tools to obtain information.

Meanwhile, their worst ratings are in the use of models to explore complex topics. For the Slovakians their highest levels of competency are in interaction and collaboration using digital resources and the application of digital tools to obtain information. The area where they receive the lowest evaluation is the one related to the use of models to explore complex topics.

According to this data we can say that Serbian students have higher levels of competencies in basic activities such as the use of applications and the use of the main informatics resources.

\subsection{Application competencies}

In the Application Competencies are the questions related to the use that is given to ICT in various fields. Activities such as the creation of work as a medium of expression, the planning, as well as the resolution of problems through digital resources, the participation in groups that use these tools and effective communication using a variety of informatics resources (Fig. 3.). 


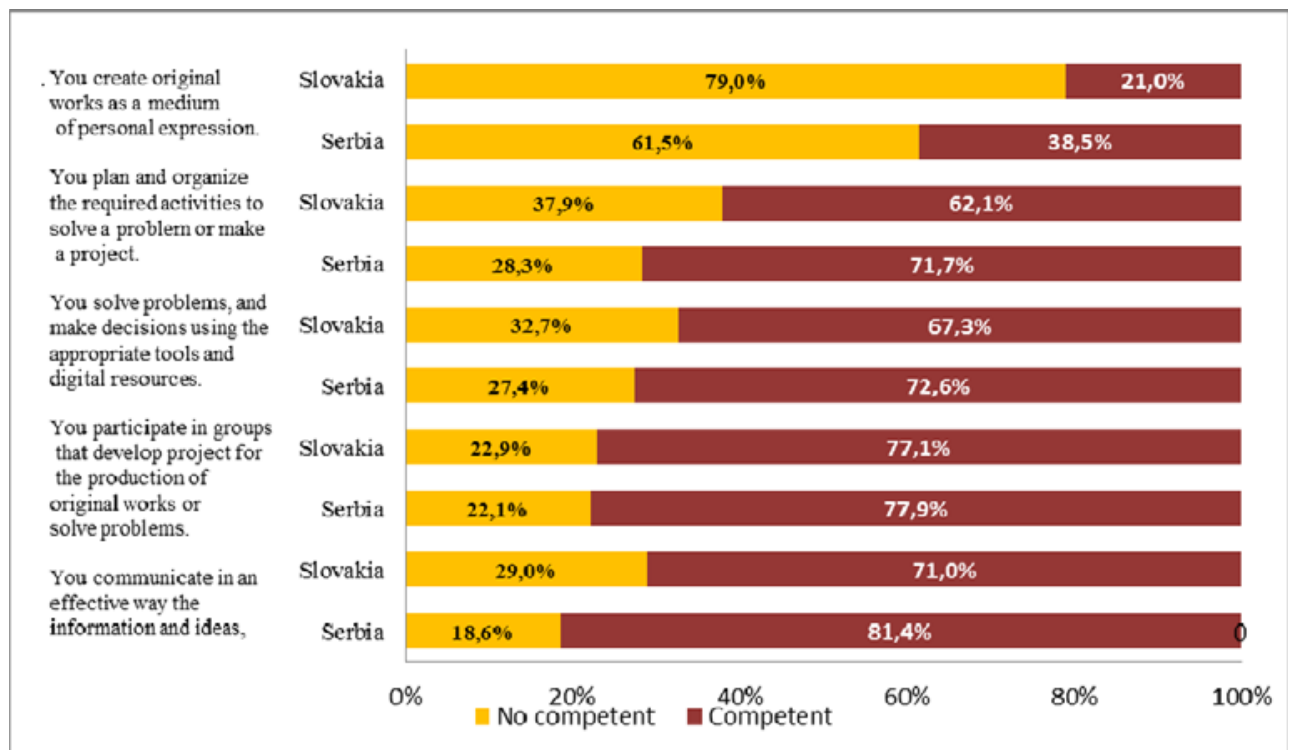

Fig. 3. Application Competencies: Level of Competency (\%)

Within this dimension we find an acceptable level of competency for the students of both countries. An exception occurs regarding the creation of work as a medium of personal expression, where the Slovakian students $(21.0 \%)$ show certain levels of non-competency, while the Serbian students consider themselves competent (38,5\%), so the Slovakian students say that their major level of non-competency $(79.0 \%)$ is in the participation in groups that develop projects for the production of original work. In this same item, the Serbians show an admissible level of non-competency (61.5\%).

For the area concerning the planning and organization of activities for problem solving or carrying out projects the Serbian students $(71.7 \%)$ are once more competent in comparison to their Slovakian counterparts $(62.1 \%)$.

In relation to problem solving and decision making through digital resources, the Serbians $(72.5 \%)$ are once more competent in comparison to their Slovakian counterparts $(67.3 \%)$.

For effective communication through media and formats, the Slovakians $(29.0 \%)$ are more non-competent in comparison to their Serbian counterparts $(18.6 \%)$.

In relation to participate in groups that develop project for the production of original works or solve problems, the Serbians (77.9\%) show same level of competency than the Slovakians $(77.1 \%)$.

The Serbian students evaluate as their own highest level of competency the area of effective communication through media and formats while the area they rate as their lowest is the creation of work as a medium of personal expression.

Meanwhile, for the Slovakians, we find that their highest level of competency is participate in groups that develop project for the production of original works. Their lowest level of competency is same with the Serbians the creation of original work as a medium of communication.

\subsection{Ethical competencies}

Finally, for the dimension of Ethical competencies, we find the areas where we ask the students about their level of competency in ethical activities. These questions analyze the impression of the students about ICT as a medium of collaboration and as an instrument of learning, as well as the use that is given to the information obtained from ICT (Fig. 4.). 


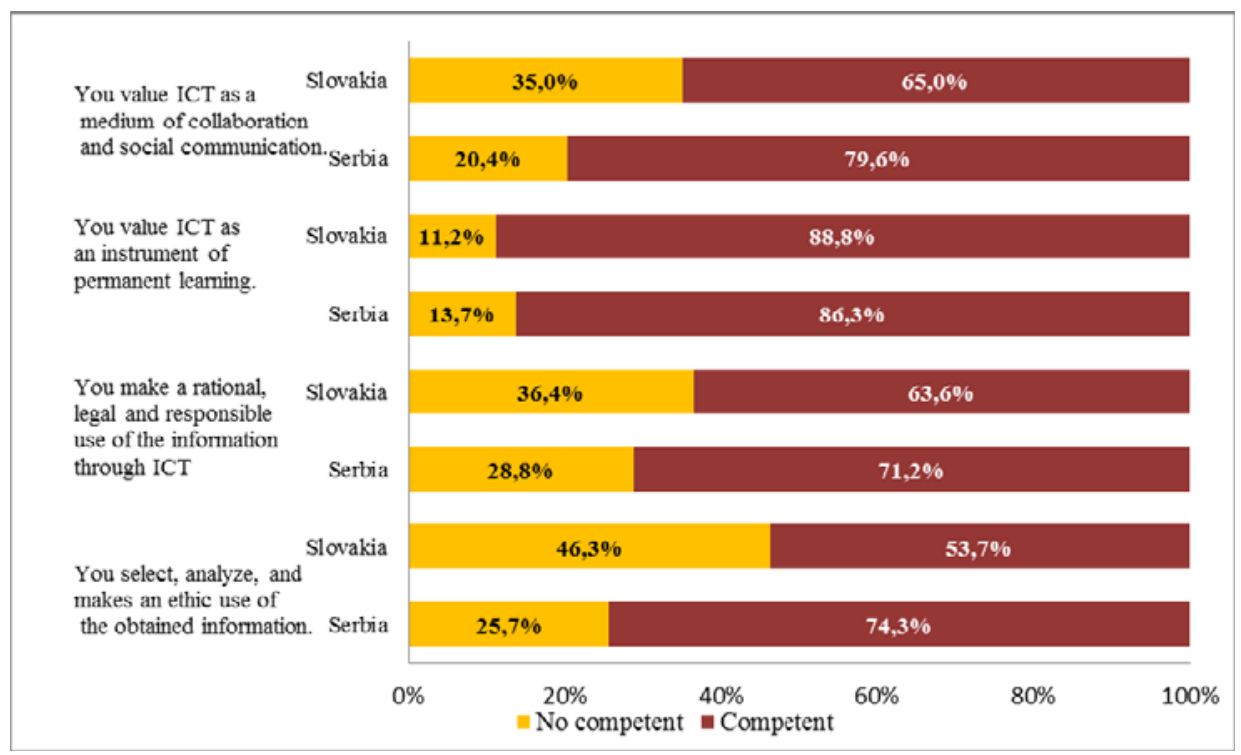

Fig. 4. Ethical Competencies: Level of Competency (\%)

The results indicate the existence of a high level of ICT competency in the students of both countries. Referring to the question of ICT as a medium of collaboration and communication, there is a higher level of competency in Serbian students $(79.6 \%)$ in comparison with the Slovakian students $(65.0 \%)$. For the area of ICT as a permanent tool for learning, there are high levels of competency in both cases: Serbian students $86.3 \%$ and Slovakian students $88.8 \%$.

Slovakian and Serbian consider using ICT as an instrument of permanent learning to be their area of highest competency. For Slovakian and Serbian students the area they felt least competent in was the legal use of the information obtained through ICT.

Serbian students show higher levels of competency in the area of ethical competencies than Slovakian students.

\section{Conclusion}

The situation of education in Serbia and Slovakia is not so very different although each country has taken a different path.

The results referring of Serbian and Slovakian Students' perceptions of their competencies in ICT indicate that they perceive a high level of competency in ICT. The students obtained a high degree of competency in the use of ICT as a permanent means of learning and as a means of social communication. The students also felt they made productive use of the various applications that are offered. The main use given to these tools is obtaining information, and they claim they make legal and responsible use of the resources.

Referring to the hypothesis we proposed, we could say that in some areas there were some significant differences between the two participating universities (University of Novi Sad and J. Selye University) in reference to the students' perceptions regarding their levels of ICT Competencies.

The differences between Slovakian and Serbian students found in the Mann-WhitheyWilcoxon test include the selection of computer resources and the use of information obtained from the network, interaction with classmates through project developing, problem solving through the use of digital tools and the choosing ICT tools a for permanent 
learning and social communication. In the rest of the areas no relevant differences were found.

Meanwhile, we found that eight questions do not receive significantly different answers.

In this document a proposed classification of Competencies in ICT (Basic, Applicationand Ethical) was presented. In these terms, the highest level obtained was for Ethical Competencies, followed by Basic Competencies and finally Application Competencies. These results suggest the need for developing strategies that promote the effective use of technology resources by students and teachers alike.

As for differences by university (J. Selye and Novi Sad), percentages indicate that there are higher levels of competencies in the Serbian students. By using the main informatics and network resources, developing project in group, using a variety of media and formats the Serbian students are more productive. The higher number of ICT lessons in Serbia shows a good way for the Serbian students to prefer teamwork over individual work what is more important in the future on the labor market.

\section{Acknowledgements}

Thank you for the teacher colleagues at University of Novi Sad for the collecting data from the students in Serbia.

\section{References}

1. García-Valcárcel, \& A. Arras, Competencias en TIC y rendimiento académico en la universidad, Diferencias por género. México: Pearson, 2011

2. A. Aypay Information and communication technology (ICT) usage and achievement of Turkish students in PISA 2006. TOJET: The Turkish Online Journal of Educational Technology, 9 (2), 116-124, 2010

3. M. Fuentes, Las competencias académicas desde la perspectiva interconductual (Academic competencies from an interbehavioral perspective). Acta Colombiana de Psicología, 10(2), 5158, 2007

4. J. Yañez-Galecio, Competencias profesionales del Psicólogo Clínico: Un análisis preliminar. Terapia Psicológica, 23(2), 85-93, 2005

5. S. Tobón. Metodología de gestión curricular. Una perspectiva socio-formativa.México: Trillas, 2013

6. NETS for students, ISTE Standards, 2007

7. UNESCO ICT competency standards for teachers, 2008

8. OECD, Education at a Glance 2013: OECD Indicators. OECD Publishing,http://dx.doi.org/10.1787/eag-2013-en, 2013

9. UNESCO Institute for Statistics International Standard Classification of Education. Canada,, 1997

10. Министарство просвете, науке и технолошког развоја (2008): Наставни програм за предмет Од играчке до рачунара за први и други разред основног образовања и васпитања. http://bit.ly/1scrO2j (2014. 03 26.)

11. Министарство просвете, науке и технолошког развоја (2008): Наставни програм образовања и васпитања за трећи разред основног образовања и васпитања. http://bit.ly/Ke3tHx (2014. 03 26.)

12. R. Likert, R, A technique for the measurement of attitudes, Archives of Psychology, Vol.: 27, No.: 140, pp 44-55, 1932

13. S. Jamieson, Likert scales: how to (ab)use them, Medical Education 2004; Vol.: 38, pp 12171218,2004

14. W. Boonyasit, Appropriate statistical analysis for two independent groups of Likert-type data, Dissertation, American University Washington, 2011

15. J. C. F. De Winter and D. Dodou, Five-Point Likert Items: t test versus Mann-WhitneyWilcoxon, Practical Assessment, Research \& Evaluation, Vol.: 15, No.: 11, ISSN: 1531-7714, 2010 